\title{
Effects of Aging and Hypertension on Plasma Angiotensin II and Platelet Angiotensin II Receptor Density
}

Joseph Duggan, Stephen Kilfeather, Eoin O'Brien, Kevin O'Malley, and Jürg Nussberger

Plasma renin activity (PRA) declines with age in normal individuals, but the effect of age on plasma angiotensin II (ANG II) is less clear. A decline in plasma ANG II with age could result in altered platelet ANG II receptor density since plasma hormone levels influence their target organ receptors. To investigate this possibility, PRA, plasma ANG II, and platelet ANG II receptor density were examined in 17 young, 12 middle-aged, and 14 elderly healthy normotensive volunteers. To assess whether hypertension altered receptor density, these variables were also examined in 23 hypertensive patients.

In normotensives, there was a negative correlation between age and PRA $(r=-0.43, P<.05)$, no significant change in basal plasma ANG II with age, and a weak positive correlation between age and ANG II receptor density $(r=0.34, P<.05)$. Multiple regression analysis revealed that the relationship between age and ANG II receptor density was independent of the associated rise in mean ar- terial pressure with age $(P<.05)$. Platelet ANG II receptor density was not significantly related to PRA or plasma ANG II. ANG II receptor affinity did not change with age. Neither PRA nor ANG II receptor density or affinity differed between hypertensives and normotensives of similar mean age, but plasma ANG II was significantly lower in hypertensives compared with normotensives.

We concluded that aging is associated with a decline in supine PRA. The small decrease in plasma ANG II was not significant. Platelet ANG II receptor density increased with age primarily due to a small group of elderly subjects with elevated receptor density. There was no change in ANG II receptor density or affinity in hypertensives despite apparently lower plasma ANG II in these patients. Am J Hypertens 1992;5:687-693.

KEY WORDS: Angiotensin II, platelet receptors, aging, hypertension.
$\mathrm{P}$ lasma renin activity declines with age in normal individuals. ${ }^{1-3}$ This is associated with a fall in plasma aldosterone with age. ${ }^{4-6}$ Most investigators have found no change in plasma angio-

Received June 25, 1991. Accepted June 30, 1992.

From the Department of Clinical Pharmacology, Royal College of Surgeons in Ireland, St. Stephens Green, Dublin, Ireland (JD, SK, EOB, KOM), and Division of Hypertension, Centre Hopitalier Universitaire Vaudois, Lausanne, Switzerland (JN).

We wish to acknowledge the support of the Health Research Board (Ireland) and the Research Committee of the Royal College of Surgeons in Ireland.

Address correspondence and reprint requests to Joseph Duggan, Department of Geriatric Medicine, University Hospital of South Manchester, Manchester, M20 8LR, England. tensin II (ANG II) with age, ${ }^{7-11}$ although there is a single report describing lower plasma ANG II levels in older normotensive subjects. This result was, however, obtained after stimulation of the renin-angiotensin system by standing for $2 \mathrm{~h} .{ }^{12}$

Reduced plasma ANG II levels, if present in the elderly, could lead to a secondary increase in ANG II receptor density and responsiveness. Vascular smooth muscle is relatively inaccessible for study in humans, but platelets appear to provide an accessible model of changes in ANG II receptor density occurring in response to changes in plasma ANG II. Platelet receptor density increases and decreases in response to sodium loading and restriction, which decrease and 
increase plasma ANG II levels ${ }^{13,14}$ in a similar fashion to changes in ANG II receptor density in vascular smooth muscle. ${ }^{15,16}$

Hypertension is associated with enhanced pressor responsiveness to ANG II. ${ }^{17}$ However, the mechanism underlying this effect is not known. It is possible that changes in ANG II receptor density or responsiveness associated with changes in circulating ANG II could be involved.

The present study was conducted therefore to ascertain the effect of age and hypertension on plasma ANG II and platelet ANG II receptor density.

\section{METHODS}

Patients and Study Design The normotensive group comprised 43 volunteers aged 20 to 74 years. All were healthy, living in the community, and were not taking any medications. Volunteers provided a medical history, and underwent a physical examination and routine hematological and biochemical screening to confirm their status as normal volunteers.

The hypertensive group comprised 23 patients aged 23 to 71 years recruited from the hypertension clinic of Beaumont Hospital, Dublin. They were either newly diagnosed or free of antihypertensive medication for at least the 4 weeks prior to the study. A diagnosis of hypertension was based on blood pressure levels above $160 / 90 \mathrm{~mm} \mathrm{Hg}$ or a diastolic (phase V) blood pressure in excess of $95 \mathrm{~mm} \mathrm{Hg}$, using a conventional mercury sphygmomanometer with the patient sitting still for 5 min, on three separate occasions. The mean arterial pressure was calculated as diastolic $+0.33 \times$ pulse pressure. All volunteers and patients gave informed consent and the protocol was approved by the Beaumont Hospital Ethical Committee.

On the morning of the study, volunteers and patients attended the department at 09:00 having fasted since 21:00. Following the insertion of an indwelling cannula for venous blood sampling and $60 \mathrm{~min}$ supine rest, the blood pressure was recorded using a Hawksley random zero sphygmomanometer. A blood sample was then withdrawn for the measurement of plasma renin activity (PRA), plasma ANG II, platelet ANG II receptor density, and affinity and serum electrolytes. Sodium status was assessed by 24 -h urinary sodium.

Laboratory Methods Plasma Renin Activity Assay We collected $10 \mathrm{~mL}$ blood into prechilled tubes containing EDTA as anticoagulant. The sample was immediately chilled in ice and centrifuged at $4^{\circ} \mathrm{C}$. Plasma was placed into prechilled cryotubes, frozen in liquid nitrogen and stored at $-80^{\circ} \mathrm{C}$ until assayed. The PRA radioimmunoassay kits were obtained from Sorin Biomedica, Saluggia, Italy (Catalog No: SB-REN-1-M). For the assay of renin activity, samples were rapidly thawed into enzyme inhibitor solution containing 2,3-dimercaptopro- pranolol and 8-hydroxyquinoline sulphate as enzyme inhibitors. Samples were then preincubated for $1.5 \mathrm{~h}$ at $37^{\circ} \mathrm{C}$ and at $\mathrm{pH} 5.5$ to 6.0 to generate angiotensin $\mathrm{I}$, or at $0^{\circ} \mathrm{C}$ to determine blank values. Assay of generated angiotensin I by radioimmunoassay was conducted in an ice-bath for $24 \mathrm{~h}$. Separation of antibody bound angiotensin I from free angiotensin I was conducted using dextran-coated charcoal according to the instructions of the kit.

Plasma ANG II Assay We collected $10 \mathrm{~mL}$ blood into prechilled plastic tubes containing $0.5 \mathrm{~mL}$ of inhibitor solution ( $2 \%$ ethanol, $25 \mathrm{mmol} / \mathrm{L}$ phenanthroline, 125 $\mathrm{mmol} / \mathrm{LNa}_{2}$-EDTA, $2 \mathrm{~g} /$ L neomycin). Blood was immediately chilled in ice and centrifuged at $4^{\circ} \mathrm{C}$. Plasma was frozen in liquid nitrogen and stored for several months at $-80^{\circ} \mathrm{C}$ until assayed. Plasma ANG II was assayed as previously described using solid-phase extraction on phenylsilylsilica, high performance liquid chromotography, and a very sensitive radioimmunoassay. ${ }^{18}$ The original description of the method mentions within- and between-assay precisions (coefficient of variation, $\mathrm{CV}$ ) of $6 \%$ and $13 \%$, respectively, for plasma containing 5.7 $\mathrm{fmol} / \mathrm{mL}$; in addition, the spiking of low renin plasma with ANG II at 2.5 and $5 \mathrm{fmol} / \mathrm{mL}$ gave recoveries with a $\mathrm{CV}$ of $12.5 \%$. In the meantime, procedures have been improved and recoveries of $6 \mathrm{fmol} / \mathrm{mL}$ are now $89 \pm$ $9 \%(n=6)$ and a sample containing $0.68 \mathrm{fmol} / \mathrm{mL}$ recently gave a $\mathrm{CV}$ of $7.5 \%$ when measured five times in the same assay. The detection limit is at $0.1 \mathrm{fmol} / \mathrm{mL}$.

Platelet ANG II Receptor Density and Affinity Materials ${ }^{125} \mathrm{I}-\mathrm{ANG}$ II was purchased from New England Nuclear (Boston, MA) at a stated specific activity of 2,200 Ci/mmol. Bovine serum albumin (BSA), bacitracin, EDTA, and Medium 199 were all from Serva (Heidelberg, Germany). [Sar ${ }^{1}-\mathrm{Leu}^{8}$ ]-ANG II was from Sigma (St. Louis, MO).

Platelet ANG II receptor density and affinity were measured using a modification of the method described by Mann and colleagues. ${ }^{19}$ We collected $30 \mathrm{~mL}$ blood into plastic tubes anticoagulated with $3.8 \%$ trisodium citrate (TSC) (TSC: blood, 1:5 mL). Platelet rich plasma (PRP) was prepared by centrifugation at $100 \mathrm{~g}$ for $15 \mathrm{~min}$ at $22^{\circ} \mathrm{C}$. PRP was removed, diluted 20 -fold with buffer (Medium 199, $5 \mathrm{mmol} / \mathrm{L}$ EDTA 0.2\% BSA, 1 $\mathrm{mg} / \mathrm{mL}$ bacitracin, $\mathrm{pH} 7.4$ at $22^{\circ} \mathrm{C}$ ) and centrifuged at $1000 \mathrm{~g}$ for $10 \mathrm{~min}$. Washing and centrifugation were repeated once and platelets were resuspended in $0.5 \mathrm{~mL}$ of this buffer. Platelets were counted manually, using a hemocytometer, and the volume adjusted to yield a final concentration of $4 \times 10^{9}$ cells $/ \mathrm{mL}$. We incubated $8 \times$ $10^{7}$ platelets with ${ }^{125} \mathrm{I}$-angiotensin ( 25 to $400 \mathrm{pmol} / \mathrm{L}$ ) in a final volume of $80 \mu \mathrm{L}$ for $120 \mathrm{~min}$ at $37^{\circ} \mathrm{C} \mathrm{mol} / \mathrm{L}$ in a shaking water bath. Duplicate samples were assayed for each concentration of labelled ANG II. Nonspecific binding was assessed by inclusion of [Sar $\left.{ }^{1}-\mathrm{Leu}^{8}\right]-\mathrm{ANG}$ II 
$\left(10^{-5} \mathrm{~mol} / \mathrm{L}\right)$ at each concentration of labelled ANG II in every experiment. Nonspecific binding ranged from 3 to $15 \%$ of the total binding at the region of the angiotensin II $K_{d}$, depending upon the level of specific binding (specific binding site density) for each individual. Incubations were terminated by dilution with $2 \mathrm{~mL}$ ice cold buffer followed by centrifugation at $2000 \mathrm{~g}$ for $5 \mathrm{~min}$ at $4^{\circ} \mathrm{C}$. From each tube $1 \mathrm{~mL}$ supernatant was removed for confirmation of free ANG II concentration. The remainder of the supernatant was discarded and the pellet resuspended in $2 \mathrm{~mL}$ ice-cold buffer and centrifuged as before. The supernatant was discarded and the radioactivity in the pellets was counted using a $\gamma$-counter at $77 \%$ count efficiency. Saturation binding curves of specifically bound radioactivity were analyzed by nonlinear regression using the computer program HYPMIC (Elsevier Scientific Publishers, B.V., Amsterdam, The Netherlands) to determine ANG II receptor density $\left(B_{\max }\right)$ and affinity $\left(K_{d}\right)$. The Hill slope for each saturation binding curve approximated to 1 ( $n=66$ [normotensive and hypertensive], median $=1.023,95 \%$ confidence interval $=1.021,1.035$ ). This suggests the presence of one ANG II binding site on the platelet, as has been previously described by others. ${ }^{19}$

Other Biochemical Methods Plasma and urinary electrolytes were measured by standard automated methods.

Statistical Analysis Where indicated the data were analyzed untransformed. Where there was evidence that a variable might not be normally distributed, reanalyses were conducted using an appropriate transformation; the summary statistics presented for such variables have been detransformed into their original units. Linear regression was performed using the computer program Microstat (Ecosoft, UK). Multiple regression was conducted with ANG II receptor density as the dependent variable and age, weight, blood pressure, PRA, plasma ANG II, and urinary sodium and potassium as independent variables. Statistical comparisons between groups were performed using analysis of variance (ANOVA) or Student's $t$ test as appropriate. Results are expressed as means with their $95 \%$ confidence limits. Significance was set at the conventional $5 \%$ level.

\section{RESULTS}

Normotensives Subjects were arbitrarily divided into three age groups for the purpose of comparison; young (20 to 32 years), middle-aged (41 to 59) and elderly (60 to 74). Baseline clinical and biochemical characteristics of the three age groups are shown in Table 1. The groups did not differ significantly in their mean body weight or serum or urinary electrolytes. Systolic, diastolic, and mean arterial pressures increased significantly with age. Plasma renin activity declined significantly with age (Table 1) and there was a negative correlation between age and PRA ( $r=.-0.43, P<.05$, Figure 1A). Plasma
ANG II was slightly but not significantly lower in elderly than young people (Table 1, Figure 1B). A single plasma ANG II measurement of $12.7 \mathrm{fmol} / \mathrm{mL}$ in a 58 year old subject was most likely due to a handling error and was therefore excluded from the analyses (the data were analysed with and without this point and the significance of the correlation between age and plasma ANG II was not altered). There was a positive correlation between PRA and plasma ANG II $(r=0.37, P<$ .01 ) and a positive correlation between age and ANG II receptor density ( $\mathrm{r}=0.34, P<.05$, Figure $1 \mathrm{C})$. Variation in ANG II receptor density increased with age. The positive correlation was primarily due to five patients over age 59 years with a substantially increased receptor density. Multiple regression revealed that age was significantly related to ANG II receptor density and when this was adjusted for, no other variables were related to ANG II receptor density. ANG II receptor affinity did not change with age. The analyses involving PRA, plasma ANG II, and platelet ANG II receptor density were repeated using only data from those subjects for whom all three measurements were available. The relationships remained unaltered, but because overall sample size was reduced, significance levels were also slightly reduced. Only those analyses using all available data are reported.

Hypertensives Hypertensive patients were compared with the middle-aged and elderly normotensive subjects who were of similar mean age. Clinical, hormonal, and receptor data of both groups are presented in Table 2. Plasma ANG II was significantly lower in hypertensives than in normotensives, but neither ANG II receptor density nor affinity differed significantly between the two groups. There was a positive correlation between PRA and plasma ANG II $(r=0.62, P<.01)$ in hypertensive patients. There was no significant correlation between age and PRA, age and plasma ANG II, or age and ANG II receptor density.

\section{DISCUSSION}

In this study the effects of age and hypertension on PRA, plasma ANG II, and platelet ANG II receptor density were examined. The results confirm that plasma renin activity falls with age. Supine plasma ANG II declined with age, but the relationship was not significant. Platelet ANG II receptor density increased with age independent of the associated rise in blood pressure, but this was primarily due to a number of patients over age 59 who had increased receptor density. Plasma ANG II levels were slightly lower in hypertensives than in normotensives, but platelet ANG II receptor density and affinity did not differ between groups.

This is the first investigation of the effect of age on basal plasma ANG II in subjects whose sodium status has been assessed. Previous investigations did not incor- 
TABLE 1. BASELINE CLINICAL, HORMONAL, AND PLATELET ANG II RECEPTOR DATA IN NORMOTENSIVES

\begin{tabular}{|c|c|c|c|}
\hline & Young & Middle-Aged & Elderly \\
\hline Age, years & $\begin{array}{c}26.7 \\
(24.8-28.6)\end{array}$ & $\begin{array}{c}50.9 \\
(46.6-55.2)\end{array}$ & $\begin{array}{c}65.3 \\
(62.8-67.8)\end{array}$ \\
\hline Weight, kg & $\begin{array}{c}67.9 \\
(61.9-73.9)\end{array}$ & $\begin{array}{c}73.5 \\
(64.6-82.4)\end{array}$ & $\begin{array}{c}71.3 \\
(63.6-79)\end{array}$ \\
\hline \multicolumn{4}{|l|}{ Blood pressure, $\mathrm{mm} \mathrm{Hg}$} \\
\hline Systolic & $\begin{array}{c}112.2 \\
(107-117)\end{array}$ & $\begin{array}{c}118.7 \\
(112-125)\end{array}$ & $\begin{array}{c}129.6^{*} \\
(119-140)\end{array}$ \\
\hline Diastolic & $\begin{array}{c}68.2 \\
(62.8-73.6)\end{array}$ & $\begin{array}{c}77.0 \\
(72.3-81.7)\end{array}$ & $\begin{array}{c}78.1^{*} \\
(73.1-83.1)\end{array}$ \\
\hline Mean & $\begin{array}{c}82.9 \\
(78.5-87.3)\end{array}$ & $\begin{array}{c}90.9 \\
(86.3-95.5)\end{array}$ & $\begin{array}{c}95.2 \dagger \\
(89.3-101)\end{array}$ \\
\hline $\mathrm{PRA}, \mathrm{ng} / \mathrm{mL} / \mathrm{h}$ & $\begin{array}{c}0.98[10] \\
(0.60-1.61)\end{array}$ & $\begin{array}{c}0.64[10] \\
(0.41-1.02)\end{array}$ & $\begin{array}{c}0.30^{*}[11] \\
(0.14-0.63)\end{array}$ \\
\hline Plasma ANG II, fmol/mL & $\begin{array}{c}3.97[16] \\
(2.97-5.31)\end{array}$ & $\begin{array}{c}3.63[8] \\
(2.90-4.53)\end{array}$ & $\begin{array}{c}3.68[10] \\
(2.80-4.81)\end{array}$ \\
\hline ANG II receptor density, fmol $/ 10^{9}$ cells & $\begin{array}{c}1.61 \\
(0.88-2.94)\end{array}$ & $\begin{array}{c}2.43 \\
(1.16-5.10)\end{array}$ & $\begin{array}{c}2.75 \\
(1.10-6.89)\end{array}$ \\
\hline Affinity, pmol/L & $\begin{array}{c}56.1 \\
(42.4-74.3)\end{array}$ & $\begin{array}{c}66.6 \\
(56.1-79.7)\end{array}$ & $\begin{array}{c}65.7 \\
(46.4-92.6)\end{array}$ \\
\hline Serum sodium, $\mathrm{mmol} / \mathrm{L}$ & $\begin{array}{l}140.5[16] \\
(140-141)\end{array}$ & $\begin{array}{c}139.9 \\
(139-141)\end{array}$ & $\begin{array}{c}140.8[13] \\
(139-142)\end{array}$ \\
\hline Serum potassium, $\mathrm{mmol} / \mathrm{L}$ & $\begin{array}{c}4.4[16] \\
(4.2-4.6)\end{array}$ & $\begin{array}{c}4.5 \\
(4.4-4.6)\end{array}$ & $\begin{array}{c}4.5[13] \\
(4.3-4.7)\end{array}$ \\
\hline Urine sodium, $\mathrm{mmol} / 24 \mathrm{~h}$ & $\begin{array}{l}144.9[16] \\
(118-172)\end{array}$ & $\begin{array}{c}157.6 \\
(121-194)\end{array}$ & $\begin{array}{c}169.2 \\
(130-209)\end{array}$ \\
\hline Urine potassium, $\mathrm{mmoL} / 24 \mathrm{~h}$ & $\begin{array}{c}81.8 \\
(65.2-98.4)\end{array}$ & $\begin{array}{c}87.1 \\
(68.4-106)\end{array}$ & $\begin{array}{c}74.8 \\
(58.9-90.7)\end{array}$ \\
\hline
\end{tabular}

Mean (95\% confidence limits for mean).

$* \mathrm{P}<.01$.

$\dagger \mathrm{P}<.001$, ANOVA.

$n=17$, young; $n=12$, middle-aged; $n=14$, elderly; unless otherwise indicated in square brackets.

porate the measurement of 24-h urinary sodium and differences in dietary sodium cannot be excluded as a reason for their findings of unchanged plasma ANG II with age..$^{7-11}$ In the present study $24-h$ urinary sodium did not differ significantly between young and old subjects and therefore could not be responsible for the finding of similar plasma ANG II in these groups. Previous investigations did not use high-performance liquid chromatography (HPLC) for the specific measurement of angiotensin-(1-8)octapeptide. In the present study, plasma derived ANG II was purified by HPLC prior to radioimmunoassay. ${ }^{18}$ Thus, the findings could provide more accurate information concerning the effect of age on plasma ANG II in humans.

The PRA fell with age, while plasma ANG II fell slightly but not significantly. This is in agreement with the findings of Skott and associates in their study of normal 85 year old people. ${ }^{11}$ On the basis of lower PRA, lower generation of ANG I and therefore ANG II would be expected. We cannot exclude a small amount of ANG II being generated in vitro after blood sampling, ${ }^{20}$ since no renin inhibitor was added to the sampling cocktail. ${ }^{21}$
However, careful and rapid handling on ice and immediate freezing of plasma would have minimized this artifact. Furthermore, in vitro generation should accentuate, rather than diminish, age-related differences in ANG II concentrations, since less ANG II is formed in vitro when less PRA and ANG $I$ is present, ${ }^{20}$ as is the case in the plasma of older subjects. Plasma angiotensin converting enzyme was not measured in the present study, but is reported to be either unchanged ${ }^{22,23}$ or decreased $^{\mathbf{2 4 , 2 5}}$ in the elderly. Alternatively, the rate of ANG II metabolism may decline with age, but this remains to be established. Furthermore, it may be necessary to stimulate the renin-angiotensin system, for example by ambulation, to accentuate and thereby detect any difference in plasma ANG II between young and old. ${ }^{12}$

The finding of a positive correlation between age and platelet ANG II receptor density supports the results of the single previous study in this area. ${ }^{26}$ However, in the previous investigation neither plasma ANG II nor urinary sodium were measured and the study was not conducted in healthy volunteers. The elderly group in the previous study were all hospital inpatients with dis- 


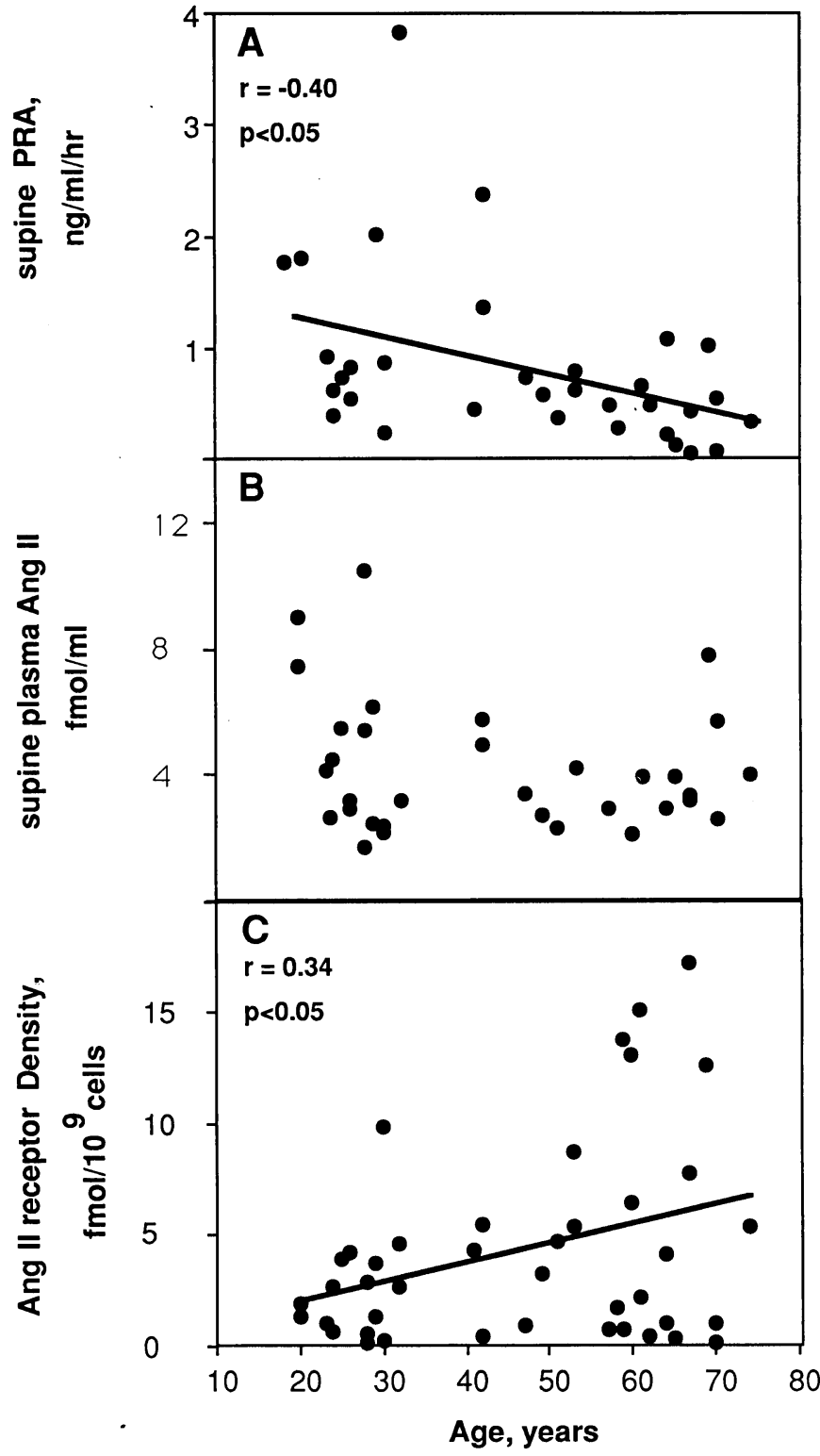

FIGURE 1. A. Correlation between age and plasma renin activity (PRA) in normotensive volunteers $(n=31)$. B. Relationship between age and plasma ANG II in normotensive volunteers ( $n=$ 34). C. Relationship between age and platelet ANG II receptor density in normotensive volunteers $(n=43)$.

eases, including coronary artery disease, hyperthyroidism and hypothyroidism; in addition, five elderly patients were hypertensive and all older subjects were receiving medication. In the present investigation none of these potentially confounding variables was present. More recently, the same investigators have found the increase in ANG II receptor density to be independent of the accompanying age-related increase in ANG II uptake processes in the platelet. ${ }^{27}$ In the present study, there was a correlation between age and platelet ANG II receptor density and increased variation with age. Although receptor density did not increase in many of the subjects over age sixty, in a small group of these patients receptor density was elevated.

Another aspect of this study concerns the relationship between plasma ANG II and platelet ANG II receptor density. From studies involving the manipulation of plasma ANG II through changes in dietary sodium it appears that ANG II receptors, in common with many other receptor types and their respective hormones, undergo reciprocal regulation by circulating ANG II. Thus, dietary sodium restriction, which increases plasma ANG II, decreases vascular smooth muscle receptor density in the rat. ${ }^{15,16}$ Human platelet ANG II receptors are regulated in a similar fashion, undergoing a reduction in receptor density ("downregulation") in response to sodium restriction. A corresponding increase in receptor density ("upregulation") occurs in response to sodium loading which is associated with reduced plasma ANG II levels..$^{13,14,28}$ The higher sodium intake in the elderly (169 $v 145 \mathrm{mmol})$ in the present investigation could only have contributed minimally to lower PRA and increased receptor density. The difference in uri-

TABLE 2. BASELINE CLINICAL, HORMONAL, AND PLATELET ANG II RECEPTOR DATA IN HYPERTENSIVES

\begin{tabular}{lcc}
\hline & Normotensives & Hypertensives \\
\hline Age, years & 58.7 & 55.0 \\
& $(55.0-62.4)$ & $(48.8-61.2)$ \\
Weight, kg & 72.3 & 70.8 \\
& $(66.9-77.7)$ & $(64.7-76.9)$ \\
Blood pressure, mm Hg & & \\
Systolic & 124.5 & $175.6^{*}$ \\
& $(118-131)$ & $(167-184)$ \\
Diastolic & 77.6 & $100.7^{*}$ \\
& $(74.4-80.8)$ & $(97.6-104)$ \\
Mean & 93.2 & $125.7^{*}$ \\
& $(89.5-96.9)$ & $(122-130)$ \\
PRA, ng/mL/h & $0.43[21]$ & $0.43[20]$ \\
& $(0.28-0.67)$ & $(0.24-0.76)$ \\
Plasma ANG II, & $3.68[18]$ & $2.77 *[20]$ \\
fmol/mL & $(3.11-4.29)$ & $(2.19-3.49)$ \\
ANG II receptor den- & 2.60 & 3.71 \\
sity, fmol/10 cells & $(1.48-4.53)$ & $(2.22-6.23)$ \\
Affinity, pmol/L & 66.1 & 66.5 \\
& $(54.5-79.7)$ & $(60.8-72.8)$ \\
Serum sodium, & $140.4[25]$ & 140.9 \\
mmol/L & $(140-141)$ & $(140-142)$ \\
Serum potassium, & $4.5[25]$ & 4.4 \\
mmol/L & $(4.4-4.6)$ & $(4.3-4.5)$ \\
Urine sodium, & 163.8 & $144.1[20]$ \\
mmol/24 h & $(139-189)$ & $(121-168)$ \\
Urine potassium, & 80.5 & $70.5[20]$ \\
mmol/24 h & $(68.9-92.1)$ & $(57.8-83.2)$ \\
\hline
\end{tabular}

Mean (95\% confidence limits for mean).

${ }^{*} \mathrm{P}<.001$, hypertensives compared to normotensives.

$n=26$, normotensives; $n=23$, hypertensives; unless otherwise indicated in square brackets. 
nary sodium was not statistically significant and there was no correlation between urinary sodium and either PRA or ANG II receptor density. Furthermore, extremes of sodium restriction ( $10 \mathrm{mEq} /$ day) and sodium loading (200 $\mathrm{mEq} /$ day) are required to demonstrate upregulation and downregulation in ANG II receptor density in platelets. ${ }^{13,14}$ It appears, therefore, that regulation of platelet ANG II receptor density during aging is complex and that factors in addition to plasma ANG II are involved. The increase in receptor density is unlikely to be due simply to an increase in platelet size with age since platelet volume remains constant from early adulthood to old age. ${ }^{29}$

In agreement with others ${ }^{\mathbf{1 4}}$ our data suggests that platelet ANG II receptor density and affinity are similar in normotensives and hypertensives. In the present study, the hypertensives and normotensives had similar PRA, but plasma ANG II was slightly lower in hypertensives. ANG II receptor density was not, however, increased in hypertensives. There was no correlation between either PRA or plasma ANG II and ANG II receptor density in the hypertensive group. It may be that plasma ANG II in the hypertensives was not sufficiently low to result in upregulation of platelet ANG II receptor density or, as in normotensives, factors in addition to circulating ANG II may also influence receptor density in hypertensives. Some patients with hypertension demonstrate enhanced pressor responsiveness to infused ANG $\mathrm{II}^{17,30}$ but factors other than increased ANG II receptor density could contribute.

In conclusion, PRA falls with age. Plasma ANG II also fell with age, but the decrease was not significant. Platelet ANG II receptor density increased with age primarily due to a small group of elderly subjects with elevated receptor density. Hypertensives with lower plasma ANG II exhibit similar platelet ANG II receptor density as normotensives.

\section{ACKNOWLEDGEMENTS}

We thank Kay McKeown, Catherine Amstutz, and Irene Keller for excellent technical assistance, Johannes Mann (Heidelberg, Germany) for advice in establishing the platelet ANG II receptor assay, and Brian Faragher (Manchester, England) for statistical advice.

\section{REFERENCES}

1. Hayduk K, Krause DK, Kaufmann W, et al: Age-dependent changes of plasma renin concentration in humans. Clin Sci Molec Med 1973;45:273-278.

2. Weidmann P, De Myttenaere, Bursztein S, et al: Effect of ageing on plasma renin and aldosterone in normal man. Kidney Int 1975;8:325-333.

3. Meade TW, Imeson JD, Gordon D, Peart WS: The epidemiology of plasma renin. Clin Sci 1983;64:273-280.

4. Sambhi MP, Crane MG, Genest J: Essential hypertension: new concepts about mechanisms. Ann Intern Med 1973;79:411-424.
5. Hegstad R, Brown RD, Jiang N, et al: Aging and aldosterone. Am J Med 1983;74:442-448.

6. Tsunoda K, Abe K, Toshikazu G, et al: Effect of age on the renin-angiotensin-aldosterone system in normal subjects: simultaneous measurement of active and inactive renin, renin substrate, and aldosterone in plasma. J Clin Endocrinol Metab 1986;62:384-389.

7. Kala R, Fyhrquist F, Eisalo A: Effect of short-term upright posture on plasma angiotensin II in man. Scand J Clin Lab Invest 1974;33:87-94.

8. Padfield PL, Nelson CS, Beevers DG, et al: Hypertension and the renin-angiotensin system in an unselected population, in Burley DM, Birwood GF, Fryer JW, Taylor SH (eds): Hypertension: Its Nature and Treatment. Horsham, UK, Ciba, 1975, pp 19-28.

9. Phillips PA, Rolls BJ, Ledingham JGG, et al: Reduced thirst after water deprivation in healthy elderly men. N Engl J Med 1984;311:753-759.

10. Ferris JB, Sullivan PA, Gonggrip JPH, et al: Plasma angiotensin II and aldosterone in unselected diabetic patients. Clin Endocrinol 1982;17:261-269.

11. Skott $P$, Ingerslev J, Nielsen $D$, Giese J: The renin-angiotensin-aldosterone system in normal 85-year-old people. Scand J Clin Lab Invest 187;47:69-74.

12. Hiramatsu K, Yamagishi F, Kubota T, Yamacla T: Acute effects of the calcium antagonist nifedipine on blood pressure, pulse rate and the renin-angiotensin-aldosterone system in patients with essential hypertension. Am Heart J 1982;104:1346-1350.

13. Moore TJ, Taylor T, Williams GH: Human platelet angiotensin II receptors: regulation by circulating angiotensin level. J Clin Endocrinol Metab 1984;58:778-782.

14. Ding Y-A, Kenyon CJ, Semple PF: Regulation of platelet receptors for angiotensin II in man. J Hypertens 1985;3:209-212.

15. Gunther S, Gimbrone MA, Alexander RW: Regulation by angiotensin II of its receptors in resistance blood vessels. Nature 1980;287:230-232.

16. Aguilera G, Catt KJ: Regulation of aldosterone secretion during altered sodium intake. J Steroid Biochem 1983;19:525-530.

17. Meier A, Weidmann P, Grimm M, et al: Pressor factors and cardiovascular pressor responsiveness in borderline hypertension. Hypertension 1981;3:367-372.

18. Nussberger J, Brunner D, Waeber B, Brunner H: True versus immunoreactive angiotensin II in human plasma. Hypertension 1985;7(suppl I):I-1 -I-7.

19. Mann JFE, Sis J, Ritz E: ${ }^{125}$ I-Angiotensin II binding to human blood cells. J Hypertens 1985;3:131-137.

20. Nussberger J, Brunner DB, Waeber B, Brunner HR: Specific measurement of angiotensin metabolites and in vitro generated angiotensin II in plasma. Hypertension 1986;8:476-482.

21. Nussberger J, Brunner DB, Waeber B, Brunner HR: In vitro renin inhibition to prevent generation of angiotensins during determination of angiotensin I and II. Life Sci 1988;42:1683-1688.

22. Hurst $P$, Lovell-Smith C: Optimized assay for serum angiotensin converting enzyme activity. Clin Chem $1981 ; 27: 2048-2052$. 
23. Romer F: Clinical and biochemical aspects of sarcoidosis - with special reference to angiotensin converting enzyme (ACE). Acta Med Scand 1984;690(suppl):1-96.

24. Beutler E, West C: Sex and age-related differences in activity of angiotensin-converting enzyme in serum (letter). Clin Chem 1983;29:1570.

25. Wiberg-Jorgensen F, Klausen N, Hald A, et al: Pulmonary angiotensin II production in respiratory failure. Clin Physiol 1983;3:59-67.

26. Siebers MJ, Goodfriend TL: Platelet angiotensin receptors in young and old humans. J Gerontol 1986;41:574578.

27. Siebers MJ, Goodfriend T, Ball D, Elliot M: Analysis of angiotensin II binding to human platelets: differences in young and old subjects. J Gerontol 1990;45:B42-B47.

28. Mann JFE, Leidig M, Ritz E: Circulating angiotensin II levels in humans correlate with angiotensin II binding capacity of platelets. J Hypertens 1986;4(suppl 6):406407.

29. Graham SS, Straub B, Mink IB: Automated platelet-sizing parameters on a normal population. Am J Clin Pathol 1987;87:365-369.

30. Meier A, Gubein U, Weidmann P, et al: Age related profile of cardiovascular reactivity to norepinephrine and angiotensin II in normal and hypertensive man. Klin Wochenschr 1980;58:1183-1188. 